\title{
PENGARUH PEMBERIAN PUPUK ORGANIK PADA MEDIA TANAH YANG MENGANDUNG TIMBAL (Pb) TERHADAP PERTUMBUHAN KANGKUNG DARAT (Ipomoea reptans Poir.)
}

\author{
THE EFFECT OF ORGANIC FERTILIZER ON SOIL MEDIA CONTAINING LEAD (PB) \\ ON THE GROWTH OF MORNING GLORY (Ipomoea peptans Poir.)
}

\author{
Listiatie Budi Utami dan Ulfah Rachmawati ${ }^{1}$ \\ Program Studi Biologi, Fakultas Matematika dan Ilmu Pengetahuan Alam \\ Universitas Ahmad Dahlan, Yogyakarta \\ Email: listiatie_uad@yahoo.com
}

\section{INTISARI}

Kangkung darat (Ipomoea reptans Poir.) merupakan tanaman hiperakumulator logam timbal (Pb), padahal kangkung darat banyak dikonsumsi oleh masyarakat. Penelitian ini bertujuan untuk mengetahui pertumbuhan dan kandungan timbal $(\mathrm{Pb})$ kangkung darat pada berbagai dosis pupuk organik; serta untuk mengetahui dosis pupuk organik yang paling efektif untuk meningkatkan pertumbuhan dan menurunkan kandungan timbal $(\mathrm{Pb})$ dalam kangkung darat. Penelitian dilakukan secara Rancangan Acak Lengkap (RAL) dengan perlakuan pemberian pupuk organik dengan dosis o gram, 50 gram, 100 gram, 150 gram, 200 gram, dan 250 gram dalam $2 \mathrm{~kg}$ tanah dari TPA Piyungan, Bantul. Setiap perlakuan diulang 4 kali dan dilakukan selama 4 minggu. Pengamatan meliputi tinggi tanaman, jumlah daun, panjang daun, panjang akar, dan berat basah tanaman. Pada minggu ke-4, dilakukan pengukuran kadar timbal (Pb) dalam daun. Dilakukan uji ANOVA dan BNT 5\%. Hasil penelitian menunjukkan bahwa pemberian pupuk organik dapat meningkatkan pertumbuhan tanaman kangkung darat. Dosis yang paling efektif untuk pertumbuhan tanaman kangkung darat adalah 200 gram dalam $2 \mathrm{~kg}$ tanah. Pemberian pupuk organik tidak dapat menurunkan kandungan $\mathrm{Pb}$ dalam tanaman kangkung darat.

Kata kunci: kangkung darat, pupuk organik, timbal (Pb)

\begin{abstract}
Morning glory (Ipomoea reptans Poir.) is a hyperacumulator plant of lead metals ( $\mathrm{Pb}$ ), while this plant consumed by humans. This research aims to determinate growth of $I$. reptans at various dosages of organic fertilizer, and to determine the most effective dosage of organic fertilizer to promote the growth and reduce the content of lead $(\mathrm{Pb})$ in $I$. reptans. This research was conducted in Completely Randomized Design (CRD) with 4 doses of organic fertilizer (o, 50, 100, 150, 200 grams and 250) in $2 \mathrm{~kg}$ soil of Piyungan, Bantul landfill. Each treatment was done in four replicates for four weeks. Observation included plant height, number of leaves, leaf length, root length, and fresh weight of plants. Measurement of the levels of lead $(\mathrm{Pb})$ was conducted in the leaves. Data analysis was performed by ANOVA and LSD 5\%. The results of this study showed that giving organic fertilizer could enhance plant growth. The most effective dosage for plant growth was 200 in $2 \mathrm{~kg}$ of soil. However organic fertilizers could not reduce the content of $\mathrm{Pb}$ in the Ipomoea reptans plant.
\end{abstract}

Key words: morning glory (Ipomoea reptans Poir), organic fertilizer, lead (Pb)

\section{PENDAHULUAN}

Tanah di sekitar area pembuangan sampah potensial tercemar logam berat. Penumpukan sampah yang terus menerus menyebabkan terakumulasinya logam berat dalam tanah tersebut. Berdasarkan hasil survei di TPA Piyungan Bantul, terlihat bahwa masih terdapat bahan-bahan berbahaya yang dibuang bersama sampah domestik, seperti aki bekas, batu baterai bekas, dan pecahan lampu TL bekas. Bahan buangan tersebut mengandung unsur timbal $(\mathrm{Pb})$ yang sangat berbahaya bagi manusia (Ganefati dkk, 2008). Bahan buangan ini dikhawatirkan menimbulkan pencemaran tanah yang berdampak pada masuknya bahan pencemar tersebut ke dalam tubuh makhluk hidup.

Kangkung merupakan tanaman sayur yang dikonsumsi oleh masyarakat. Menurut SNI No.7387-2009, batas maksimum cemaran $\mathrm{Pb}$ dalam sayuran adalah $0,5 \mathrm{mg} / \mathrm{kg}$. Berdasarkan uraian di atas, kangkung yang dikonsumsi manusia dikhawatirkan dapat menjadi media perantara masuknya timbal $(\mathrm{Pb})$ ke dalam tubuh manusia. Materi organik dalam tanaman kangkung dapat mengurangi 
keberadaan $\mathrm{Pb}$ dalam organ tanaman kangkung. Pemberian pupuk organik diharapkan dapat mencegah masuknya timbal $(\mathrm{Pb})$ ke dalam tanaman.

Menurut Darmono (2006), senyawa organik dapat mencegah pergerakan ion logam berat bergerak masuk ke dalam sistem jaringan tanaman. Logam berat dalam bentuk terlarut yang membahayakan dapat membentuk kompleks dengan bahan organik dalam tanah menjadi logam yang tidak larut. Logam yang diikat menjadi kompleks organik ini relatif tidak tersedia bagi tanaman. Hal tersebut tidak berlaku untuk tanaman hiperakumulator. Menurut McGrath et al. (1997), tumbuhan hiperakumulator memiliki kemampuan untuk melarutkan unsur logam pada rizosfer dan menyerap logam bahkan dari fraksi tanah yang tidak bergerak. Salt (2000), juga menjelaskan bahwa tumbuhan hiperakumulator memiliki kemampuan lebih tinggi dalam mengubah logam pada zona perakaran menjadi bentuk yang tersedia.

Penelitian ini dilakukan untuk mengetahui pengaruh pemberian pupuk organik terhadap pertumbuhan dan kadar timbal $(\mathrm{Pb})$ pada kangkung darat (Ipomoea reptans Poir.) yang ditanam di tanah TPA Piyungan, serta untuk mengetahui dosis pupuk organik yang paling berpengaruh terhadap pertumbuhan dan kadar timbal $(\mathrm{Pb})$ pada kangkung darat.

\section{MATERI DAN METODE}

Penelitian dilakukan di Jetis, Bantul DIY pada bulan Februari-Mei 2015 menggunakan tanaman kangkung, pupuk organik berbahan dasar limbah sayuran. Media tanah yang berasal dari TPA Piyungan dicampur pupuk organik dengan dosis $0,50,100,150,200$, dan 250 dalam $2 \mathrm{~kg}$ tanah. Parameter penelitian diantaranya: tinggi tanaman, jumlah daun, panjang daun, panjang akar, berat basah tanaman, kadar timbal $(\mathrm{Pb})$ pada daun, dan pengukuran kondisi abiotik meliputi $\mathrm{pH}$ media tanam, suhu dan kelembapan lingkungan. Rancangan Penelitian adalah Rancangan Acak Lengkap (RAL). Data dianalisis dengan uji ANOVA, dilanjutkan dengan uji BNT pada taraf $5 \%$.

\section{HASIL}

Kandungan timbal $(\mathrm{Pb})$ pada media tanam ditampilkan pada Tabel 1. Kandungan Pb pada tanah TPA Piyungan adalah $26,952 \mathrm{mg} / \mathrm{kg}$ dengan kadar air sebesar $6.77 \%$

Tabel 1. Hasil Uji Kadar Timbal (Pb) dalam Tanah TPA Piyungan

\begin{tabular}{ccccc}
\hline No & Parameter & Satuan & HasilUji & MetodeUji \\
\hline 1. & Timbal $(\mathrm{Pb})$ & $\mathrm{mg} / \mathrm{kg}$ & 26,953 & USEPA 3051, SW846- \\
& & & & 7000B:2007 \\
2. & Kadar air & $\%$ & 6,77 & SNI 1965-2008 \\
\hline
\end{tabular}

Pertumbuhan Ipomoea reptans Poir diamati berdasarkan tinggi tanaman jumlah daun, panjang daun, panjang akar, dan berat basah tanaman. Pengaruh pupuk organik terhadap tinggi tanaman ditampilkan pada Gambar 1, Dari hasil ANOVA diketahui bahwa nilai signifikansi lebih kecil dari 0,05. Pemberian pupuk organik pada dosis $50 \mathrm{~g}, 100 \mathrm{~g}, 150 \mathrm{~g}, 200 \mathrm{~g}$ dan $250 \mathrm{~g}$ meningkatkan tinggi tanaman.

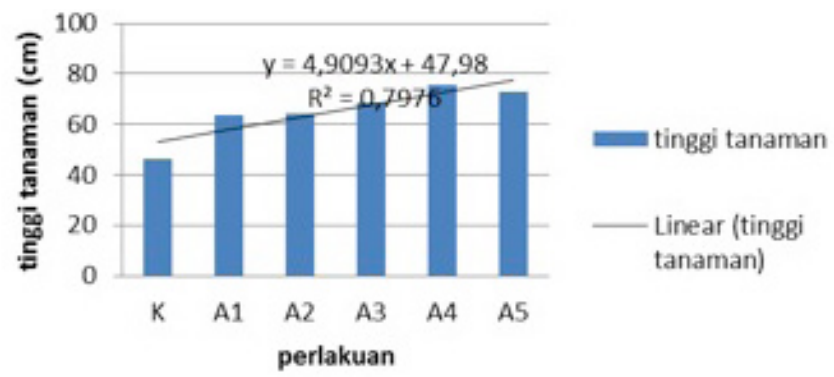

Gambar 1. Diagram rerata tinggi tanaman kangkung darat pada minggu ke-4

Keterangan $: \mathrm{K}=\mathrm{O} \mathrm{g}, \mathrm{A} 1=50 \mathrm{~g}, \mathrm{~A} 2=100 \mathrm{~g}, \mathrm{~A} 3=150 \mathrm{~g}$, $\mathrm{A} 4=200 \mathrm{gdan} \mathrm{A}_{5}=250 \mathrm{~g}$

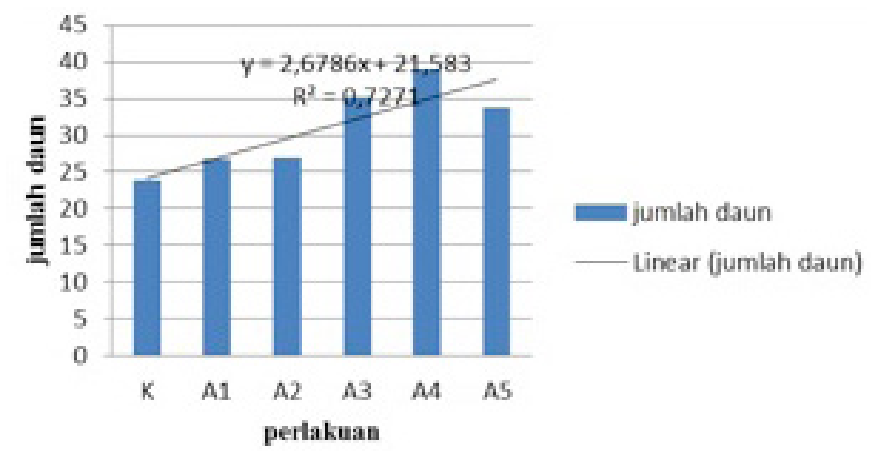

Gambar 2. Diagram rerata jumlah daun tanaman kangkung darat pada minggu ke-4

Rerata jumlah daun akibat pemberian pupuk organik disajikan pada Gambar 2. Dari hasil ANAVA diketahui bahwa nilai signifikansi lebih kecil dari 0,05. Setiap perlakuan secara signifikan meningkatkan jumlah daun.

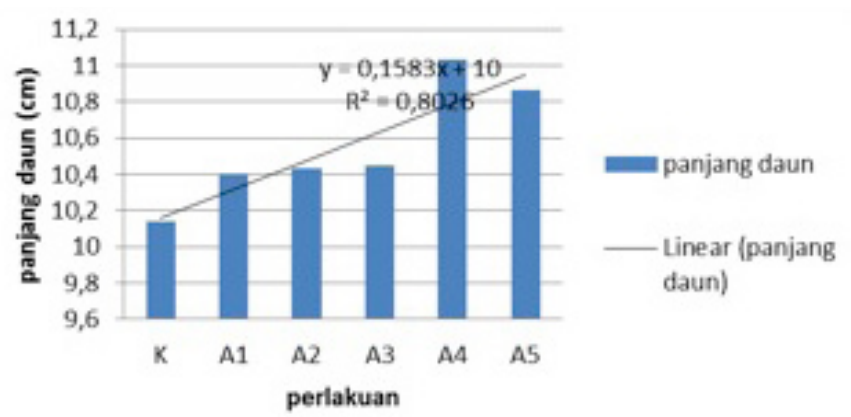

Gambar 3. Diagram rerata panjang daun tanaman kangkung darat pada minggu ke-4

Gambar 3 menunjukkan rerata panjang daun tanaman kangkung darat, sedangkan Gambar 4 menunjukkan rerata panjang akar. Rerata berat basah tanaman kangkung akibat pemberian pupuk organik pada tanah yang mengandung $\mathrm{Pb}$ ditampilkan pada Gambar 5. 


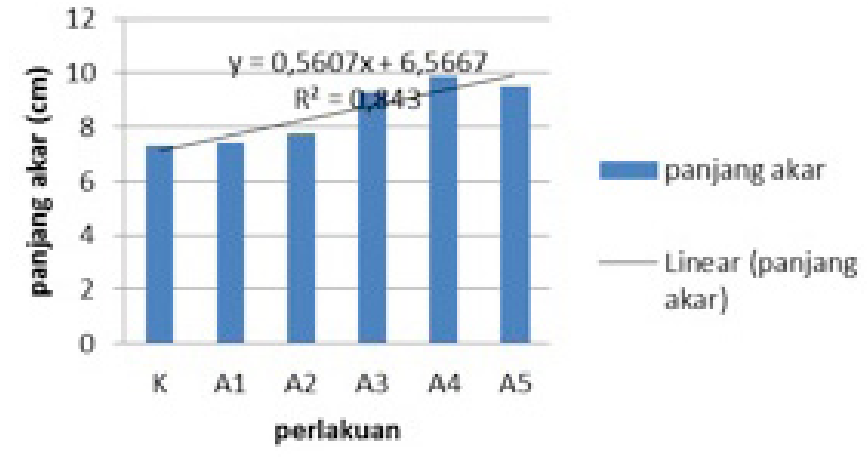

Gambar 4. Diagram rerata panjang akar tanaman kangkung darat

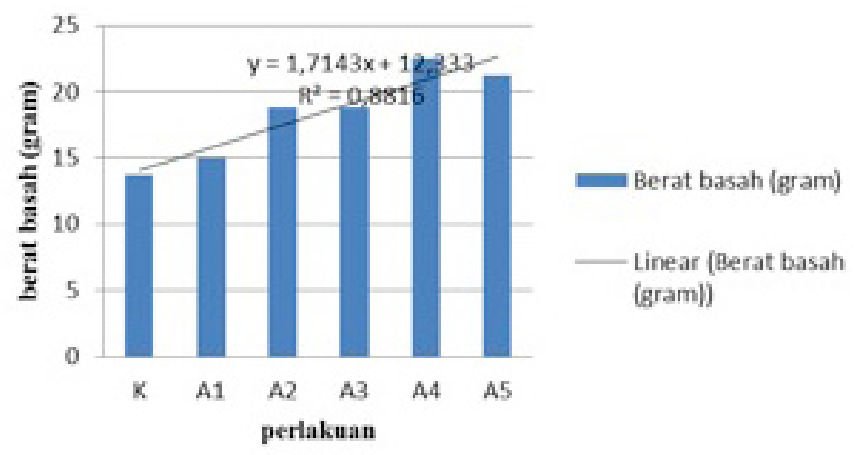

Gambar 5. Diagram rerata berat basah tanaman kangkung darat

Dari hasil ANOVA diketahui bahwa pemberian pupuk organik dengan dosis yang berbeda akan memberikan hasil berat basah yang berbeda pula. Secara umum terjadi peningkatan berat basah tanaman, dengan meningkatnya dosis pupuk organik yang diberikan.

Pengukuran kadar timbal $(\mathrm{Pb})$ pada daun kangkung dilakukan setelah minggu ke-4. Hasil pengukuran kadar timbal $(\mathrm{Pb})$ dapat dilihat pada Gambar 6..

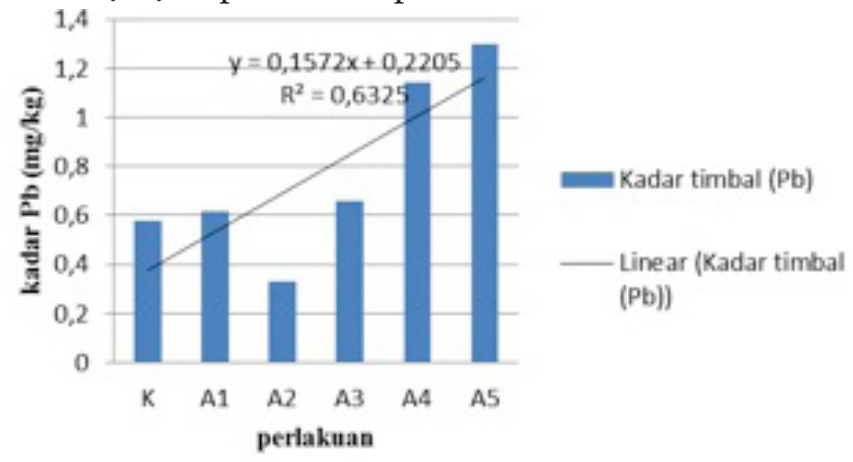

Gambar 6. Diagram kadar timbal (Pb) pada daun kangkung darat

Pengukuran kondisi abiotik lingkungan pemeliharaan tanaman kangkung darat meliputi derajat keasaman (pH) media tanam, suhu dan kelembapan udara. Hasil pengukuran menunjukkan $\mathrm{pH}$ media tanam kangkung darat berkisar antara 6-7, sedangkan suhu udara berkisar antara $28-33^{\circ} \mathrm{C}$ dan kelembapan udara berkisar antara 6o-82\%. Kondisi abiotik menunjukkan bahwa $\mathrm{pH}$, kelembapan dan suhu udara pada tempat penelitian memenuhi syarat yang baik untuk tanaman kangkung darat.

\section{PEMBAHASAN}

Darmono (1995) menyebutkan bahwa kandungan timbal $(\mathrm{Pb})$ dalam tanah secara alamiah adalah 10 $\mathrm{mg} / \mathrm{kg}$. Berdasarkan Tabel 1. dapat diketahui bahwa kandungan timbal $(\mathrm{Pb})$ dalam tanah TPA Piyungan melebihi kandungan secara alamiah. Kandungan $\mathrm{Pb}$ dalam tanah TPA Piyungan di bawah batas kritis $\mathrm{Pb}$ dalam tanah yang ditetapkan oleh Ministry of State for Population and Enviromental of Indonesia, and Dalhousie, University Canada (1992), yaitu $100 \mathrm{mg} / \mathrm{kg}$.

Pada perlakuan pupuk organik terhadap tinggi tanaman, hasil ANOVA menunjukkan nilai signifikansi lebih kecil dari o,05. Hal ini berarti pemberian pupuk organik dengan dosis yang berbeda akan memberikan hasil tinggi tanaman yang berbeda pula. Hasil uji BNT terlihat bahwa tinggi tanaman kangkung darat pada perlakuan $\mathrm{K}$ beda nyata dengan perlakuan $\mathrm{A} 3$, A4, dan A5, tetapi tidak beda nyata dengan perlakuan A1 dan A2.

Perlakuan K (o pupuk organik) menghasilkan ratarata tinggi tanaman yang paling rendah dibandingkan perlakuan lain. Pemberian pupuk organik dengan berbagai dosis menghasilkan tanaman yang lebih tinggi dibandingkan tanpa pemberian pupuk organik. Hal ini disebabkan karena pemberian pupuk organik dapat meningkatkan ketersediaan unsur hara terutama unsur nitrogen (N) yang sangat dibutuhkan untuk pertumbuhan vegetatif tanaman. Jumin (2002) menyatakan bahwa nitrogen berfungsi untuk merangsang penambahan tinggi tanaman.

Hasil analisis kandungan unsur pada pupuk organik yang dilakukan oleh BBTKL Yogyakarta, menunjukkan bahwa pupuk organik yang diberikan mengandung unsur $\mathrm{N}, \mathrm{P}$, dan $\mathrm{K}$ yang cukup sehingga kebutuhan unsur hara yang diperlukan tanaman untuk pertumbuhannya akan memadai. Perlakuan A4 (200 pupuk organik) mengandung unsur nitrogen $(\mathrm{N})$ yang sesuai dengan kebutuhan tanaman kangkung darat bila dibandingkan dengan perlakuan lain. Hal ini dapat dijelaskan bahwa dosis 200 merupakan dosis optimal bagi tanah dalam penyediaan unsur hara. Sedangkan dosis berikutnya yaitu 250 tanah mengalami kejenuhan sehingga proses penyerapann kedalam akar tanaman mengalami hambatan, yang berakibat pada menurunnya pertumbuhan. Dengan demikian, metabolisme maupun pertumbuhan tanaman yang dihasilkan pada dosis 200 gram lebih optimal, jika dibandingkan dengan perlakuan lain.

Hasil uji BNT pada taraf 5\% menunjukkan bahwa jumlah daun tanaman kangkung darat pada perlakuan $\mathrm{K}$, A1, dan A2 beda nyata dengan perlakuan A3, A4, dan A5. Tetapi perlakuan K tidak beda nyata dengan perlakuan A1 dan A2, kemudian perlakuan A3 tidak beda nyata dengan 
perlakuan A4 dan A5. Berdasarkan hasil tersebut jumlah daun yang paling sedikit adalah pada tanaman perlakuan K (o pupuk organik). Pemberian pupuk organik dengan berbagai dosis menghasilkan jumlah daun yang lebih banyak dibandingkan dengan tanpa pupuk organik. Hal ini disebabkan karena pemberian pupuk organik dapat meningkatkan ketersediaan unsur nitrogen $(\mathrm{N})$ dan fosfor (P). Nyakpa, dkk (1988) menyatakan bahwa nitrogen dan fosfor berperan dalam pembentukan sel-sel baru dan komponen utama penyusun senyawa organik dalam tanaman seperti asam amino, asam nukleat, klorofil, ADP dan ATP.

Perlakuan A4 (200 pupuk organik) memberikan hasil jumlah daun yang paling banyak jika dibandingkan dengan perlakuan lain. Hal ini dapat disebabkan karena pada perlakuan A4 mengandung unsur hara nitrogen $(\mathrm{N})$ dan fosfor (P) yang sesuai dengan kebutuhan tanaman kangkung darat bila dibandingkan dengan perlakuan lain.Terjadinya peningkatan jumlah daun pada tanaman juga berhubungan dengan pertambahan tinggi tanaman. Apabila tanaman semakin tinggi, maka jumlah titik tumbuh daun semakin banyak, sehingga jumlah daun semakin banyak.

Pada pengamatan panjang daun, hasil ANOVA menunjukkan tidak ada beda nyata antar perlakuan, maka tidak dilanjutkan dengan uji BNT. Meskipun pemberian pupuk organik tidak memberikan hasil yang beda nyata terhadap panjang daun kangkung darat, rerata panjang daun yang paling tinggi terdapat pada perlakuan A4 (200 pupuk organik), sedangkan pada perlakuan K (tanpa pupuk organik) hasilnya paling rendah dibandingkan dengan perlakuan yang lain. Lakitan (1996), menyatakan bahwa tanaman yang tidak mendapat tambahan nitrogen akan tumbuh kerdil, daun yang terbentuk lebih kecil, tipis, dan jumlahnya lebih sedikit sedangkan tanaman dengan unsur nitrogen yang cukup maka akan memiliki daun lebih banyak dan lebar.

Pemberian pupuk organik dengan dosis yang berbeda akan memberikan hasil panjang akar yang berbeda pula. Dari hasil uji BNT pada taraf 5\% terlihat bahwa panjang akar tanaman kangkung darat pada perlakuan K, A1, dan A2 beda nyata dengan perlakuan A3, A4, dan A5. Perlakuan K tidak beda nyata dengan perlakuan A1 dan A2. Kemudian perlakuan A3 tidak beda nyata dengan perlakuan A4 dan A5.

Berdasarkan hasil penelitian, rata-rata panjang akar yang paling rendah adalah perlakuan $\mathrm{K}$ (o gram pupuk organik), sehingga menunjukkan bahwa pemberian pupuk organik dengan berbagai dosis menghasilkan panjang akar yang lebih tinggi dibandingkan dengan tanpa pupuk organik. Pupuk organik dapat menambah unsur hara yang penting untuk pertumbuhan akar yaitu nitrogen (N). Apabila nitrogen diserap oleh akar, maka daerah meristem apikal pada ujung akar akan aktif membelah sehingga akar semakin terpacu pertumbuhannya.

Perlakuan A4 (200 gram pupuk organik) memberikan hasil panjang akar yang paling optimal jika dibandingkan dengan perlakuan lain. Hal ini dapat disebabkan karena pada perlakuan A4 mengandung unsur nitrogen (N) yang sesuai dengan kebutuhan tanaman kangkung darat bila dibandingkan dengan perlakuan lain. Hal ini menyebabkan metabolisme maupun pembelahan sel meristem apikal pada ujung akar dapat bekerja dengan optimal sehingga panjang akar yang dihasilkan juga optimal. Hasil ini sesuai dengan pendapat Maria (2009) bahwa pupuk yang dibutuhkan untuk tanaman kangkung sebesar 100 hingga 250 per $\mathrm{kg} / \mathrm{ha}$ tanah.

Sistem perakaran mempunyai peran yang sangat penting dalam pertumbuhan dan perkembangan tanaman. Akar menyerap air dan unsur hara disamping menopang berdirinya tanaman di tanah. Akar juga menghasilkan substansi pertumbuhan (zat pengatur tumbuh) yang diperlukan bagi tumbuhnya tanaman secara normal (Ambarwati, 2004).

Hasil uji BNT pada taraf $5 \%$ terlihat bahwa berat basah tanaman kangkung darat pada perlakuan $\mathrm{K}$ beda nyata dengan perlakuan A2, A3, A4 dan A5, tetapi tidak beda nyata dengan perlakuan A1. Perlakuan A2 tidak beda nyata dengan perlakuan A3. Perlakuan A4 tidak berbeda nyata dengan A5 serta perlakuan A5 tidak beda nyata dengan A2, A3, dan A4.

Berdasarkan hasil penelitian, rata-rata berat basah yang paling rendah adalah perlakuan K (o pupuk organik), sehingga menunjukkan bahwa pemberian pupuk organik dengan berbagai dosis menghasilkan berat basah yang lebih tinggi dibandingkan dengan tanpa pupuk organik. Peningkatan berat basah tidak terlepas dari peningkatan unsur hara seperti nitrogen, posfor, dan kalium. Nitrogen mempengaruhi pembentukan sel-sel baru, fosfor berperan dalam pengaktifan enzim-enzim dalam proses fotosintesis dan kalium mempengaruhi perkembangan jaringan meristem yang dapat mempengaruhi panjang dan lebar daun. Dengan demikian, terjadinya peningkatan berat basah berhubungan dengan pertambahan tinggi tanaman dan jumlah daun yang signifikan serta kecendrungan helaian daun yang semakin panjang.

Tanaman dengan perlakuan A4 (200 pupuk organik) memiliki rata-rata berat basah yang paling tinggi jika dibandingkan dengan perlakuan yang lain. Hal ini disebabkan karena perlakuan A4 memiliki rata-rata tinggi tanaman, jumlah daun, dan panjang daun yang paling tinggi dibandingkan perlakuan lain, sehingga proses fotosintesis lebih optimal dan jumlah air yang terkandung dalam organ tanaman lebih tinggi daripada perlakuan lain. Menurut Salisbury dan Ross (1995), berat basah berhubungan dengan banyaknya air yang diserap, senyawa yang dibutuhkan dalam jumlah besar pada setiap organ, tetapi kandungan air dari suatu jaringan tanaman dapat berubah atau tidak stabil sesuai dengan umur.

Tujuan pengukuran berat basah tanaman adalah untuk memperoleh gambaran keseluruhan biomassa pertumbuhan tanaman. Harjadi (1991), menyatakan bahwa ketersediaan unsur hara berperan penting sebagai sumber energi sehingga tingkat kecukupan hara berperan 
dalam mempengaruhi biomassa dari suatu tanaman. Lingga (1994), juga mengemukakan jika unsur hara yang dibutuhkan tanaman tersedia dalam jumlah yang cukup, maka hasil metabolisme seperti sintesis biomolekul akan meningkat. Hal ini menyebabkan pembelahan dan pemanjangan sel, menjadi lebih sempurna dan cepat, sehingga pertumbuhan tanaman menjadi lebih baik.

Diagram kadar $\mathrm{Pb}$ pada daun kangkung darat (Gambar 6) menunjukkan bahwa tanaman kangkung darat dapat menyerap timbal $(\mathrm{Pb})$ dari media pertumbuhannya. Menurut Darmono (2006), logam berat dalam bentuk terlarut yang membahayakan dapat membentuk kompleks dengan bahan organik dalam tanah menjadi logam yang tidak larut. Logam yang diikat menjadi kompleks organik ini relatif tidak tersedia bagi tanaman. Dengan demikian senyawa organik dapat mencegah pergerakan ion logam berat masuk ke dalam sistem jaringan tanaman. Namun, ternyata teori tersebut tidak berlaku untuk tanaman kangkung darat. Semakin tinggi dosis pupuk organik, kadar timbal $(\mathrm{Pb})$ dalam daun kangkung darat semakin meningkat. Hal ini dikarenakan semakin tinggi dosis pupuk organik, semakin banyak jumlah nitrogen (N) yang diserap oleh tanaman. Dengan demikian, protein yang terbentuk semakin banyak. Sehingga, pembentukan fitokelatin semakin meningkat.

Eddy (2010) menyebutkan bahwa kangkung merupakan salah satu tanaman hiperakumulator, yaitu relatif tahan timbal $(\mathrm{Pb})$ dan mengakumulasikannya dalam jaringan dengan jumlah yang cukup besar. Menurut McGrath et al. (1997), proses fisiologis yang berperan dalam akumulasi logam oleh tumbuhan antara lain interaksi rizosferik, yaitu proses interaksi akar tanaman dengan media tumbuh. Dalam hal ini, tumbuhan hiperakumulator memiliki kemampuan untuk melarutkan unsur logam pada rizosfer dan menyerap logam bahkan dari fraksi tanah yang tidak bergerak. Salt (2000) juga menjelaskan bahwa tumbuhan hiperakumulator memiliki kemampuan lebih tinggi dalam mengubah logam pada zona perakaran menjadi bentuk yang tersedia. Tumbuhan hiperakumulator juga diperkirakan melepaskan kelat untuk logam yang spesifik ke rizosfer oleh akar.

Menurut Haryati dkk. (2012), lingkungan yang banyak mengandung logam berat timbal $(\mathrm{Pb})$, membuat protein regulator dalam tumbuhan tersebut membentuk senyawa pengikat yang disebut fitokelatin. Fitokelatin dibentuk di dalam nukleus kemudian melewati retikulum endoplasma, aparatus golgi, vasikula sekretori untuk sampai ke permukaan sel. Bila bertemu dengan timbal $(\mathrm{Pb})$ serta logam berat lainnya, fitokelatin akan membentuk senyawa kompleks sehingga timbal $(\mathrm{Pb})$ dan logam berat lainnya akan terbawa menuju jaringan tumbuhan.
Dari hasil penelitian, kadar timbal $(\mathrm{Pb})$ di dalam daun kangkung darat setelah minggu ke-4 lebih dari 0,5 $\mathrm{mg} / \mathrm{kg}$. Berdasarkan SNI 7387:2009, batas maksimum cemaran timbal $(\mathrm{Pb})$ dalam sayuran yaitu sebesar 0,5 $\mathrm{mg} / \mathrm{kg}$. Hal ini menunjukkan bahwa cemaran timbal $(\mathrm{Pb})$ dalam tanaman kangkung darat telah melebihi batas maksimum, sehingga tidak aman untuk dikonsumsi.

\section{SIMPULAN}

Pemberian pupuk organik pada berbagai dosis dapat meningkatkan pertumbuhan kangkung, namun tidak mampu menurunkan kandungan timbal $(\mathrm{Pb})$ pada daun kangkung. Dosis pupuk organik yang paling berpengaruh terhadap pertumbuhan dan kandungan timbal $(\mathrm{Pb})$ tanaman kangkung darat adalah 200 dan 250 dalam $2 \mathrm{~kg}$ tanah.

\section{UCAPAN TERIMA KASIH}

Terima kasih kami haturkan kepada Dekan FMIPA Universitas Ahmad Dahlan, kepala Laboratorium Biologi dan laboran Biologi yang telah banyak berpartisipasi dalam pelaksanaan penelitian ini. Semoga kebaikan bapak ibu akan mendapat pahala dari Allah SWT.

\section{KEPUSTAKAAN}

Ambarwati, E. 2004. Budidaya Tanaman Sayuran. UGM Press. Yogyakarta.

Badan Standarisasi Nasional. 2009. SNI 7387-2009. Batas Maksimum Cemaran Logam Berat dalam Pangan. BSN. Jakarta.

Darmono, 1995. Logam Berat dalam Sistem Biologi. UI Press. Jakarta.

Darmono. 2006. Lingkungan Hidup dan Pencemaran : Hubungannya Dengan Toksikologi Senyawa Logam. UI Press. Jakarta.

Eddy, S. 2010. Kemampuan Enceng Gondok Sebagai Agen Fitoremediasi Air Tercemar Timbal (Pb). J. Sainmatika 6(2):1-7.

Ganefati, S.P. 2008. Pengolahan Leachate Tercemar Pb sebagai Upaya Pencegahan Pencemaran Lingkungan TPA. Jurusan Kesehatan Lingkungan, Poltekkes Depkes Yogyakarta. Yogyakarta.

Hasibuan, B.E. 2006. Pupuk dan Pemupukan. Universitas Sumatera Utara Press. Medan.

Maria, G.M. 2009. Respon Produksi Tanaman Kangkung Darat (Ipomea reptans Poir) Terhadap Variasi Waktu Pemberian Pupuk Kotoran Ayam. J. Ilmu Tanah 7(1): 18-22

Salt, D.E. 200o. Phytoextraction: Present Applications and Future Promise. Di dalam: Wise, D.L., D.L. Trantolo, E.J. Cichon, H.I. Inyang, U. Stottmeister. Bioremediation of Contaminated Soils. New York: Marcek Dekker Inc.

Sutanto, R. 2002. Penerapan Pertanian Organik; Pemasyarakatan dan Pengembangannya. Kanisius.Yogyakarta. 